\title{
PERBEDAAN SIKAP TERHADAP KEMATIAN BERDASARKAN KARAKTERISTIK PERAWAT
}

\author{
Mori Agustina br Perangin-angin
}

Fakultas Ilmu Keperawatan Universitas Advent Indonesia, Jl. Kolonel Masturi no 288, Parongpong, Bandung Barat

Email: mori.peranginangin@unai.edu

\begin{abstract}
Dealing with death never will become of experience of all nurses looking forward to, yet, this is unescapable situation they have to encounter. Death attitude is the most important factors influencing the healthcare's professionalism. This descriptive correlation study was conducted to 95 nurses at Rumah Sakit Advent using convenience sampling technique. Data collection was conduct by distributing questionnaires. The instrument used was the Death Attitudes Profile-Revised (DAP-R) questionnaire consisting of 32 statements using 7-point Likert scales. This study aimed to identify the death attitudes based on nurses' characteristics using Mann-Whitneyney and Kruskal Wallis test. The result of this study were there is no significant difference in death attitude in term of gender, level of education, length of work and palliative training ( $p$ value > 0.05). It is needed further study to identify factors that influence nurses' death attitudes and develop strategies to enhance positive attitudes towards death.
\end{abstract}

Keywords: death attitudes, nurse, paliative

\begin{abstract}
ABSTRAK
Menghadapi kematian bukan pengalaman yang diharapkan perawat, namun perawat tidak bisa menghindari situasi tersebut. Sikap terhadap kematian merupakan salah satu faktor yang paling penting yang mempengaruhi prilaku profesional tenaga kesehatan. Penelitian deskriptif korelasi ini dilakukan terhadap 95 orang perawat di Rumah Sakit Advent Bandung yang dipilih dengan teknik convenience sampling. Pengumpulan data dilakukan dengan membagikan kuesioner. Instrumen yang digunakan adalah kuesioner Death Attittudes Profile-Revised (DAP-R) yang terdiri dari 32 pernyataan dengan 7 skala Likert. Penelitian ini bertujuan untuk mengidentifikasi perbedaan sikap terhadap kematian berdasarkan karakteristik perawat dengan menggunakan uji non parametric Mann-Whitney dan Kruskal Wallis. Hasilnya adalah tidak terdapat perbedaan yang signifikan dalam sikap menghadapi kematian berdasarkan jenis kelamin, tingkat pendidikan, lama kerja dan pelatihan paliatif ( mempengaruhi sikap perawat terhadap kematian dan mengembangkan strategi untuk meningkatkan sikap yang positif terhadap kematian.
\end{abstract}

Kata kunci: Sikap terhadap kematian, perawat, paliatif

\section{Pendahuluan}

Kelahiran dan kematian merupakan bagian alamiah dalam kehidupan manusia yang dapat menimbulkan perasaan yang sangat bertolak belakang. Kebanyakan orang tidak mau memikirkan tentang kematian karena dapat menimbulkan rasa takut dan sedih. Perawat sebagai salah satu bagian dari tenaga kesehatan yang paling lama berhadapan dengan pasien seringkali harus menghadapi pasien menjelang ajal. Wessel \& Garon, (2005) menyatakan bahwa sikap terhadap kematian merupakan salah satu faktor yang paling penting yang mempengaruhi prilaku profesional tenaga kesehatan. 
Ada banyak bukti yang menunjukkan bahwa menghadapi pasien menjelang ajal bukanlah peristiwa yang menyenangkan bagi perawat. Penelitian yang dilakukan oleh Mak, Chiang, dan Chui, (2013) kepada perawat di salah satu rumah sakit di Hongkong menunjukkan bahwa perawat mengalami tekanan mental yang cukup besar dalam melaksanakan peran mereka merawat pasien menjelang ajal. Hal ini disebabkan oleh kurangnya kesiapan dalam menghadapi kematian pasien. Perawat seringkali merefleksikan arti kematian dan pengalaman mereka dalam menghadapi kematian anggota keluarga mereka sendiri. Level kecemasan perawat serta bagaimana mekanisme koping perawat terhadap kematian mempengaruhi kemampuan mereka dalam memberikan asuhan keperawatan kepada pasien menjelang ajal (Boyle \& Carter, 2013).

Sikap perawat terhadap kematian adalah tingkah laku yang ditampilkan oleh perawat dalam dalam merawat pasien menjelang ajal ataupun yang sudah meninggal. Ada banyak faktor yang mempengaruhi sikap seseorang terhadap kematian, misalnya iman, etnis, pendidikan, sosial ekonomi dan karakteristik agama (Randhawa, 2012); umur, jenis kelamin, pengalaman, dan lain sebagainya (Khader \& Alasad, 2010). Penelitian yang dilakukan oleh Hasheesh, et al (2013) terhadap 155 perawat Jordania menunjukkan bahwa sikap perawat terhadap kematian dipengaruhi oleh umur dan pengalaman kerja. Perawat yang mempunyai pengalaman kerja lebih lama mempunyai sikap yang lebih positif terhadap kematian.

Unit kerja perawat juga dapat mempengaruhi sikap perawat terhadap kematian, hal ini sesuai dengan penelitian Payne, et al (1998) yang menyatakan bahwa perawat yang bekerja di hospis menunjukkan tingkat kecemasan yang lebih rendah dibandingkan perawat unit gawat darurat. Hal ini disebabkan oleh karena perawat yang bekerja di hospis lebih banyak menghabiskan waktunya merawat pasien menjelang ajal dibandingkan perawat emergensi.

Faktor lain yang mempengaruhi sikap perawat terhadap kematian adalah pelatihan paliatif. Penelitian yang dilakukan Andersson, Salickiene, dan Rosengren, (2016) terhadap enam orang perawat di dua unit keperawatan bedah di Swedia menunjukkan bahwa kurangnya pengetahuan tentang perawatan paliatif membuat perawat merasa tidak siap menghadapi pasien menjelang ajal. Ketidaksiapan ini menimbulkan rasa cemas, stress dan burnout. Khader, (2010) menyatakan bahwa program pendidikan seperti pelatihan efektif untuk meningkatkan kualitas perawatan kepada pasien menjelang ajal. Hal ini mendukung penelitian yang dilakukan oleh Matsui \& Braun, (2010) bahwa perawat yang mengikuti seminar atau pelatihan tentang pasien menjelang ajal mempunyai sikap yang lebih positif dibandingkan mereka yang tidak mengikuti pelatihan.

Gesser, Wong, dan Reker (1987) menyatakan ada tiga sikap manusia terhadap kematian yaitu: 1). Takut kematian, yaitu ketakutan secara sadar dan spesifik terhadap kematian; 2). Penghindaran kematian, yaitu ketika seseorang lebih memilih untuk tidak memikirkan atau membicarakan tentang kematian. Dan ini merupakan sikap yang negatif; 3). Penerimaan kematian, yang merupakan fase akhir dari proses koping terhadap kematian. Kondisi ini merupakan kesiapan individu dalam menghadapi perpisahan dengan 
kehidupan. Menurut Wong, Reker, \& Gesser, (1994), ada tiga sikap yang ditunjukkan dalam penerimaan kematian, yaitu: 1). Menerima kematian sebagai bagian alamiah. Ini terjadi ketika seseorang memandang kematian sebagai bagian integral dari kehidupan. Walaupun tidak takut mati tetapi tidak juga melihat kematian sebagai pengalaman yang menyenangkan; 2). Menantikan kehidupan setelah kematian, melihat kematian sebagai bagian dari akhir kehidupan yang lebih baik. 3). Menerima kematian sebagai bentuk kelepasan dari penderitaan dalam hidup. Hal ini biasanya terjadi pada orang yang mengalami kesakitan dan kesedihan dalam hidup, sehingga mereka menganggap kematian lebih baik daripada terus menerus menderita. Menurut Nozari \& Dousti, (2013), menerima kematian sebagai bagian alami, menerima kematian sebagai kelepasan dari penderitaan, dan menantikan kehidupan setelah kematian merupakan sikap yang positif. Sebaliknya sikap yang negatif adalah takut terhadap kematian dan menghindari kematian.

Rumah Sakit Advent adalah salah satu rumah sakit tipe B di Bandung yang memberikan layanan rawat jalan dan rawat inap, baik unit medikal bedah, unit kritis, unit hemodialisa, dan lain sebagainya. Perawat yang bekerja disana juga seringkali harus berhadapan dengan pasien menjelang ajal. Menurut data yang penulis dapatkan bahwa masih banyak perawat yang belum mendapatkan pelatihan paliatif. Oleh karena itu penulis tertarik melakukan penelitian untuk mengetahui perbedaan sikap terhadap kematian berdasarkan karakteristik perawat di Rumah Sakit Advent Bandung.
Penelitian kuantitatif dengan desain deskriptif korelasi ini dilakukan terhadap 95 orang perawat di Rumah Sakit Advent Bandung setelah terlebih dahulu mendapatkan ijin etik dari Komite Etik Fakultas Ilmu Keperawatan Universitas Advent Indonesia dan ijin penelitian dari institusi yang dimaksud. Pemilihan sampel dilakukan dengan teknik convenience sampling yang dilakukan pada bulan Oktober sampai November 2019. Perawat yang bersedia menjadi partisipan diminta mengisi kuesioner setelah menandatangani informed consent.

Instrumen yang digunakan adalah kuesioner yang dikembangkan oleh Wong, Reker, \& Gesser, (1994) yaitu kuesioner Death Attittudes ProfileRevised (DAP-R) yang terdiri dari 32 pernyataan yang dibagi menjadi 5 subkategori, yaitu takut terhadap kematian (7 pernyataan), menghindari kematian (5 pernyataan), menerima kematian sebagai bagian alamiah (5 pernyataan), menerima kematian sebagai bentuk kelepasan dari penderitaan (5 pernyataan), menantikan kehidupan setelah kematian (10 pernyataan) dan terdiri dari 7 skala Likert. Semakin tinggi takut terhadap kematian dan menghindari kematian menunjukkan sikap yang negatif terhadap kematian. Sebaliknya semakin tinggi nilai penerimaan terhadap kematian menunjukkan sikap yang positif terhadap kematian. Uji validitas dan reliabilitas sudah dilakukan dibeberapa penelitian. Keseluruhan reliabilitas mencapai $82 \%$ menggunakan cronbach's alpha (Wong, et al 1994; Bagherian, Iranmanesh, Abbasszadeh, 2010). Dalam penelitian ini yang dilakukan adalah uji hasil terjemahan dengan back translation method.

Analisa univariate dilakukan untuk menentukan frekuensi dan persentase.

\section{Metode}


Setelah melakukan uji normalitas dengan Kolmogorov-smirnov dan hasilnya data tidak terdistribusi normal, maka uji non parametric Mann-Whitney dan Kruskal Wallis dilakukan untuk mengidentifikasi apakah terdapat perbedaan sikap terhadap kematian berdasarkan karakteristik perawat, yaitu jenis kelamin, tingkat pendidikan, lama kerja, dan pelatihan paliatif.

\section{Hasil}

Data distribusi partisipan berdasarkan jenis kelamin, lama kerja tingkat pendidikan, serta pelatihan mengenai perawatan paliatif dapat dilihat dalam tabel 1 .

Tabel 1. Distribusi karakteristik responden $(\mathrm{N}=95)$

\begin{tabular}{llll}
\hline Variabel & Kategori & $\mathrm{f}$ & $\%$ \\
\hline Jenis & Laki-laki & 9 & 9.5 \\
Kelamin & Perempuan & 86 & 90.5 \\
\hline Lama Kerja & 1-10 tahun & 53 & 55.8 \\
& 11-20 tahun & 30 & 31.6 \\
& 21-30 tahun & 12 & 12.6 \\
\hline Tingkat & D3 & 23 & 24.2 \\
Pendidikan & S1 & 71 & 74.7 \\
& S2 & 1 & 1.1 \\
\hline Pelatihan & Pernah & 16 & 16.8 \\
Paliatif & Belum & 79 & 83.2 \\
\hline
\end{tabular}

Tabel 1 menunjukkan bahwa sebagian besar partisipan adalah perempuan (90.5\%), dengan lama kerja 1-10 tahun (55.8\%), dan tingkat pendidikan S1 (74.7\%), serta $83.2 \%$ belum pernah mendapat pelatihan paliatif.

Tabel 2. Nilai rerata sikap terhadap kematian $(\mathbf{n}=95)$

\begin{tabular}{lcccc}
\hline $\begin{array}{l}\text { Sikap terhadap } \\
\text { kematian }\end{array}$ & Mean & SD & Min & Max \\
\hline $\begin{array}{l}\text { Takut terhadap } \\
\text { kematian }\end{array}$ & 28.57 & 4.269 & 20 & 40 \\
\hline
\end{tabular}

\begin{tabular}{lllll}
$\begin{array}{l}\text { Menghindari } \\
\text { kematian }\end{array}$ & 19.93 & 4.043 & 9 & 30 \\
\hline $\begin{array}{l}\text { Menerima } \\
\text { kematian } \\
\text { sebagai bagian }\end{array}$ & 12.13 & 4.494 & 5 & 29 \\
alamiah & & & & \\
\hline $\begin{array}{l}\text { Menerima } \\
\text { kematian }\end{array}$ & & & & \\
$\begin{array}{l}\text { sebagai } \\
\text { kelepasan dari }\end{array}$ & 20.01 & 3.975 & 11 & 33 \\
penderitaan & & & & \\
\hline $\begin{array}{l}\text { Menantikan } \\
\text { kehidupan }\end{array}$ & & & & \\
setelah & 39.25 & 4.951 & 26 & 52 \\
kematian & & & & \\
\hline
\end{tabular}

Data pada tabel 2 menunjukkan bahwa nilai rerata sikap terhadap kematian partisipan paling tinggi pada aspek 'menantikan kehidupan setelah kematian' (39.25), kemudian 'takut terhadap kematian' (28.57), 'menerima kematian sebagai kelepasan dari penderitaan' (20.1), dan 'menghindari kematian' (19.93). Sedangkan nilai rerata terendah adalah menerima kematian sebagai bagian alamiah (12.13).

Tabel 3. Perbedaan sikap terhadap kematian berdasarkan jenis kelamin (Mann-Whitney)

\begin{tabular}{llll}
\hline $\begin{array}{l}\text { Sikap terhadap } \\
\text { kematian }\end{array}$ & $\begin{array}{l}\text { Jenis } \\
\text { Kelamin }\end{array}$ & Mean & Sig \\
\hline $\begin{array}{l}\text { Takut terhadap } \\
\text { kematian }\end{array}$ & Laki laki & 62.28 & .100 \\
Perempuan & 46.51 & \\
\hline $\begin{array}{l}\text { Menghindari } \\
\text { kematian }\end{array}$ & Laki laki & 47.17 & .923 \\
\hline $\begin{array}{l}\text { Menerima } \\
\text { kematian } \\
\text { sebagai bagian } \\
\text { alamiah }\end{array}$ & Perempuan & 48.09 & \\
\hline $\begin{array}{l}\text { Menerima } \\
\text { kematian } \\
\text { sebagai } \\
\text { kelepasan dari } \\
\text { penderitaan }\end{array}$ & Laki laki & 51.00 & .729 \\
\hline
\end{tabular}




\begin{tabular}{llll}
$\begin{array}{l}\text { Menantikan } \\
\text { kehidupan }\end{array}$ & Laki laki & 37.06 & .208 \\
$\begin{array}{l}\text { setelah } \\
\text { kematian }\end{array}$ & Perempuan & & \\
\hline
\end{tabular}

Berdasarkan nilai rerata pada tabel 3 dapat dilihat bahwa partisipan laki laki lebih takut terhadap kematian, menerima kematian sebagai bagian alamiah, dan menerima kematian sebagai kelepasan dari penderitaan dibandingkan perempuan. Sebaliknya wanita lebih menghindari kematian dan menanti kehidupan dibalik kematian dibandingkan laki laki. Nilai signifikansi dari kelima aspek tersebut $>0.05$ berarti tidak ada perbedaan sikap terhadap kematian antara laki laki dan perempuan.

Tabel 4. Perbedaan sikap terhadap kematian berdasarkan tingkat pendidikan (Kruskal-Wallis)

\begin{tabular}{lllll}
\hline $\begin{array}{l}\text { Sikap } \\
\text { terhadap } \\
\text { kematian }\end{array}$ & $\begin{array}{l}\text { Tingkat } \\
\text { pendidi } \\
\text { kan }\end{array}$ & $\mathrm{N}$ & Mean & Sig \\
\hline $\begin{array}{l}\text { Takut } \\
\text { terhadap }\end{array}$ & $\mathrm{D} 3$ & 23 & 51.28 & .797 \\
kematian & $\mathrm{S} 1$ & 71 & 47.00 & \\
\hline Menghinda & $\mathrm{D} 3$ & 23 & 48.67 & .796 \\
ri kematian & $\mathrm{S} 1$ & 71 & 48.04 & \\
& $\mathrm{~S} 2$ & 1 & 30.00 & \\
\hline $\begin{array}{l}\text { Menerima } \\
\text { kematian }\end{array}$ & $\mathrm{D} 3$ & 23 & 38.07 & .071 \\
$\begin{array}{l}\text { sebagai } \\
\text { bagian } \\
\text { alamiah }\end{array}$ & $\mathrm{S} 2$ & 71 & 50.74 & \\
\hline $\begin{array}{l}\text { Menerima } \\
\text { kematian }\end{array}$ & $\mathrm{D} 3$ & 23 & 49.59 & .923 \\
$\begin{array}{l}\text { sebagai } \\
\text { kelepasan } \\
\text { dari }\end{array}$ & $\mathrm{S} 1$ & 71 & 47.40 & \\
penderitaan & & 1 & & \\
\hline $\begin{array}{l}\text { Menantika } \\
\text { n }\end{array}$ & $\mathrm{D} 3$ & 23 & 49.50 & .852 \\
$\begin{array}{l}\text { kehidupan } \\
\text { setelah } \\
\text { kematian }\end{array}$ & $\mathrm{S} 1$ & 71 & 47.70 & \\
\hline & $\mathrm{S} 2$ & 1 & 34.50 & \\
\hline
\end{tabular}

Nilai rerata pada tabel 4 menunjukkan bahwa partisipan dengan tingkat pendidikan D3 lebih takut mati (51.28), menghindari kematian (488.7), dan menantikan kehidupan setelah kematian (49.50) dibandingkan partisipan $\mathrm{S} 1$ dan S2. Nilai rerata tertinggi partisipan yang menerima kematian sebagai bagian alamiah dan menerima kematian sebagai kelepasan dari penderitaan adalah mereka dengan tingkat pendidikan S2. Namun nilai signifikansi pada kelima aspek diatas $>0.05$, yang berarti tidak ada perbedaan sikap antara partisipan dengan tingkat pendidikan D3, S1 dan S2.

Tabel 5. Perbedaan sikap terhadap kematian berdasarkan lama kerja (Kruskal-Wallis)

\begin{tabular}{|c|c|c|c|}
\hline $\begin{array}{l}\text { Sikap terhadap } \\
\text { kematian }\end{array}$ & $\begin{array}{c}\text { Lama } \\
\text { kerja } \\
\text { (tahun) }\end{array}$ & Mean & Sig \\
\hline \multirow{3}{*}{$\begin{array}{l}\text { Takut terhadap } \\
\text { kematian }\end{array}$} & $1-10$ & 49.94 & \multirow[t]{3}{*}{.681} \\
\hline & $11-20$ & 46.63 & \\
\hline & $21-30$ & 42.83 & \\
\hline \multirow{3}{*}{$\begin{array}{l}\text { Menghindari } \\
\text { kematian }\end{array}$} & $1-10$ & 45.63 & \multirow[t]{3}{*}{.623} \\
\hline & $11-20$ & 50.55 & \\
\hline & $21-30$ & 52.08 & \\
\hline \multirow{3}{*}{$\begin{array}{l}\text { Menerima } \\
\text { kematian } \\
\text { sebagai bagian } \\
\text { alamiah }\end{array}$} & $1-10$ & 49.37 & \multirow[t]{3}{*}{.611} \\
\hline & $11-20$ & 48.48 & \\
\hline & $21-30$ & 40.75 & \\
\hline \multirow{3}{*}{$\begin{array}{l}\text { Menerima } \\
\text { kematian } \\
\text { sebagai } \\
\text { kelepasan dari } \\
\text { penderitaan }\end{array}$} & $1-10$ & 47.91 & \multirow[t]{3}{*}{.987} \\
\hline & $11-20$ & 47.70 & \\
\hline & $21-30$ & 49.17 & \\
\hline \multirow{3}{*}{$\begin{array}{l}\text { Menantikan } \\
\text { kehidupan } \\
\text { setelah kematian }\end{array}$} & $1-10$ & 45.53 & \multirow[t]{3}{*}{.070} \\
\hline & $11-20$ & 56.70 & \\
\hline & $21-30$ & 37.17 & \\
\hline
\end{tabular}

Nilai rerata pada tabel 5 menunjukkan bahwa responden dengan lama kerja 110 tahun paling takut terhadap kematian dan menerima kematian sebagai bagian alamiah. Sedangkan responden dengan 
lama kerja 11-20 tahun paling menantikan kehidupan setelah kematian. Responden dengan lama kerja 20-30 tahun lebih menerima kematian sebagai kelepasan dari penderitaan. Nilai signifikansi pada semua aspek diatas > 0.05. Hal ini berarti tidak terdapat perbedaan sikap terhadap kematian (death attitude) berdasarkan lama kerja.

Nilai rerata yang ada pada tabel 6 menunjukkan bahwa responden yang telah mengikuti pelatihan paliatif lebih takut terhadap kematian, dan menantikan kehidupan setelah kematian. Sebaliknya responden yang belum mengikuti pelatihan paliatif lebih menghindari kematian, menerima kematian sebagai bagian alamiah dan menerima kematian sebagai kelepasan dari penderitaan. Namun tidak terdapat perbedaan sikap terhadap kematian antara responden yang sudah menerima pelatihan dan yang belum. Hal ini dapat dilihat dari nilai sig $>0.05$.

Tabel 6. Perbedaan sikap terhadap kematian berdasarkan pelatihan paliatif (Mann-Whitney).

\begin{tabular}{llcl}
\hline $\begin{array}{l}\text { Sikap } \\
\text { terhadap } \\
\text { kematian }\end{array}$ & $\begin{array}{l}\text { Pelatihan } \\
\text { paliatif }\end{array}$ & Mean & Sig \\
\hline $\begin{array}{l}\text { Takut } \\
\text { terhadap } \\
\text { kematian }\end{array}$ & Pernah & 48.13 & .984 \\
\hline $\begin{array}{l}\text { Menghindari } \\
\text { kematian }\end{array}$ & Pernah & 44.72 & .595 \\
\hline $\begin{array}{l}\text { Menerima } \\
\text { kematian } \\
\text { sebagai } \\
\text { bagian } \\
\text { alamiah }\end{array}$ & Belum & 48.66 & \\
\hline $\begin{array}{l}\text { Menerima } \\
\text { kematian } \\
\text { sebagai }\end{array}$ & Belum & 47.03 & .876 \\
$\begin{array}{l}\text { kelepasan } \\
\text { dari }\end{array}$ & Belum & 48.20 & \\
\hline
\end{tabular}

penderitaan

\begin{tabular}{lccc}
$\begin{array}{l}\text { Menantikan } \\
\text { kehidupan }\end{array}$ & Pernah & 49.44 & .818 \\
$\begin{array}{l}\text { setelah } \\
\text { kematian }\end{array}$ & Belum & & \\
\hline
\end{tabular}

Data pada tabel 7 menunjukkan bahwa terdapat hubungan yang signifikan antara takut terhadap kematian dengan menerima kematian sebagai bagian alamiah, dengan nilai sig $0.014<0.05$.

\section{Pembahasan}

Hasil penelitian ini menunjukkan bahwa laki laki lebih takut terhadap kematian walaupun menerima kematian sebagai bagian alamiah dan menerima kematian sebagai kelepasan dari penderitaan dibandingkan perempuan. Sebaliknya wanita lebih menghindari kematian dan menanti kehidupan dibalik kematian dibandingkan laki laki. Hal ini berbeda dengan hasil penelitian Asadpour, et al (2015) bahwa rasa takut terhadap kematian lebih tinggi pada perempuan dibandingkan laki laki. Namun ada persamaan hasil, yaitu wanita lebih menantikan kehidupan setelah kematian dibandingkan laki laki. Dalam penelitian ini nilai sig > 0.05 menunjukkan terdapat perbedaan sikap terhadap kematian antara laki laki dan perempuan. Hal ini kemungkinan disebabkan karena proporsi yang tidak seimbang antara partisipan laki laki dan perempuan.

Partisipan dengan tingkat pendidikan D3 lebih menunjukkan bahwa walaupun mereka takut terhadap kematian dan menghindari kematian (tidak mau memikirkan dan membicarakan kematian), namun bila kematian itu datang mereka tetap menantikan kehidupan setelah kematian. Partisipan 
dengan tingkat pendidikan S2 lebih menerima kematian sebagai bagian alamiah dan menerima kematian sebagai kelepasan dari penderitaan. Walaupun demikian tidak terdapat perbedaan sikap terhadap kematian berdasarkan tingkat pendidikan. Hal ini dapat dilihat dari nilai sig $>0.05$. Tidak banyak literatur yang membahas tentang hal ini. Namun bila mengkaji kurikulum dalam pendidikan keperawatan dari D3, S1 hingga S2 tidak terlihat bahwa semakin tinggi jenjang pendidikan perawat maka semakin dalam materi tentang kematian yang diterima. Materi tentang kematian bukanlah materi yang berkelanjutan dari level pendidikan terendah hingga tertinggi.

Partisipan dengan lama kerja 1-10 tahun paling takut terhadap kematian namun lebih menerima kematian sebagai bagian alamiah. Sedangkan partisipan dengan lama kerja 11-20 tahun paling menantikan kehidupan setelah kematian. Partisipan dengan lama kerja 20-30 tahun lebih menerima kematian sebagai kelepasan dari penderitaan. Hal ini mendukung hasil penelitian Asadpour, et al (2015) bahwa responden dengan masa kerja lebih sedikit mempunyai rasa takut terhadap kematian lebih besar dan mereka yang bekerja lebih dari 20 tahun lebih menantikan kehidupan setelah kematian. Penelitian yang dilakukan oleh Horrero, Sabado, dan Omega, (2012); Zyga, et al (2011) menunjukkan bahwa perawat dengan pengalaman dan masa kerja lebih panjang mempunyai sikap terhadap kematian yang lebih positif (takut terhadap kematian dan menghindari kematian lebih rendah). Atau dengan kata lain, semakin sedikit masa kerja perawat maka rasa takut terhadap kematian semakin tinggi dan semakin menghindari kematian. Dalam penelitian ini, nilai sig > 0.05, yang berarti tidak terdapat perbedaan sikap terhadap kematian berdasarkan lama kerja. Hal ini mendukung penelitian Inci, (2009) bahwa sikap terhadap kematian tidak dipengaruhi lama kerja. Dari beberapa hasil penelitian diatas dapat dilihat bahwa semakin lama seorang perawat bekerja, maka semakin berkurang rasa takut terhadap kematian. Hal ini mungkin disebabkan karena perawat yang sudah mempunyai masa kerja lebih lama, sudah lebih banyak mengalami pengalaman dalam merawat pasien menjelang ajal. Selain itu, semakin lama bekerja maka umur perawat juga semakin matang dalam pemikiran dan bersikap

Hasil penelitian ini menunjukkan bahwa partisipan yang telah mengikuti pelatihan paliatif lebih takut terhadap kematian dan menantikan kehidupan setelah kematian dibandingkan mereka yang belum pernah mengikuti pelatihan paliatif. Partisipan yang belum mengikuti pelatihan paliatif lebih menghindari kematian dibandingkan partisipan yang sudah mengikuti pelatihan, namun mereka menerima kematian sebagai bagian alamiah dan menerima kematian sebagai kelepasan dari penderitaan. Nilai sig $>0.05$ menunjukkan bahwa tidak terdapat perbedaan sikap terhadap kematian antara responden yang sudah menerima pelatihan dan yang belum. Berbeda dengan penelitian Asadpour, et al (2015) bahwa rasa takut terhadap kematian 
lebih tinggi pada mereka yang belum mendapat pelatihan paliatif. Penelitian yang dilakukan oleh Inci, (2009) terhadap perawat di Turkey menunjukkan bahwa mereka yang mendapat pelatihan selama 90 menit dalam sehari selama 7 minggu menunjukkan penurunan rasa takut terhadap kematian yang signifikan. Namun hasil dalam penelitian ini bertolak belakang dengan kebanyakan hasil penelitian, sehingga perlu untuk dikaji lebih dalam jenis pelatihan, lama pelatihan dan kedalaman materi yang diterima oleh perawat. Selain itu jumlah partisipan yang sudah pernah mendapat pelatihan paliatif pada studi ini jauh lebih sedikit daripada yang belum pernah mendapat pelatihan. Proporsi yang tidak seimbang ini juga dapat mengakibatkan hasil tidak ada perbedaan dalam sikap.

\section{Kesimpulan}

Sikap yang positif terhadap kematian diperlukan perawat sebagai tenaga kesehatan yang profesional dalam memberikan asuhan keperawatan yang berkualitas kepada pasien menjelang ajal. Dalam penelitian ini didapatkan hasil bahwa tidak terdapat perbedaan sikap terhadap kematian berdasarkan jenis kelamin, lama kerja, tingkat pendidikan serta pelatihan. Perlu dilakukan kajian yang lebih dalam tentang faktor faktor lain dan melakukan strategi yang dapat meningkatkan sikap positif perawat terhadap kematian. Pelatihan tentang paliatif perlu diberikan kepada perawat sesuai dengan kebutuhan institusi dengan menyesuaikan durasi dan isi materi.

\section{Daftar pustaka}

Anderssona, E., Salickiene, Z. \& Rosengren, K., (2016). To be involved : A qualitative study of nurses' experiences of caring for dying patients. Nurse Education Today, Volume 38, Pages 144149.

Asadpour, M., Bidaki, R., Mostafavi, S.A., Karimaddini, Z.K. Ghorbanpoor, M.J., (2015). Attitude toward death in nursing staffs in hospitals of Rafsanjan (South East Iran). Nursing practice today, Volume 2 no 2.

Bagherian S, Iranmanesh S \& Abbasszadeh A., (2010). Comparison of bam and kerman nursing students' attitude about death and dying. J Qual Res Health Sci, volume 9, pages 5460.

Boyle, M., Carter, D.E., (2013). Death anxiety amongst nurses. International Journal of Palliative Nursing, volumel. 4, No. 1

Braun, M., Gordon, D., \& Uziely, B., (2010). Associations between oncology nurses' attitudes toward death and caring for dying patients. Oncology Nursing Forum, volume 37(1).

Gesser, G., Wong, P.T.P., \& Reker, G.T. (1987). Death attitudes across the life-span: The development and validation of the Death Attitude Profile (DAP). Omega: Journal of Death and Dying, volume 18, pages 113-128.

Hasheesh, M.O., AboZeid, S.A., ElSaid, S.G., Alhujaili, A.D., (2013). Nurses' characteristics 
and their attitudes toward death and caring for dying patients in a public hospital in Jordan. Health science journal, volume 7 (4).

Herrero A, Sabado J, Omega G.B., (2012). Death attitudes and emotional intelligence in nursing students. Omega, volume 66 (1), pages 39-55.

Inci F., (2009). Effects of death education on nurses' death anxiety, depression regarding death, and attitudes towards the dying patient. Anadolu Psikiyatri Dergisi, volume 10, pages 25360.

Khader K, Jarrah S, Alasad J., (2010). Influences of nurses' characteristics and education on their attitudes towards death and dying: A review of literature. International Journal of Nursing and Midwifery, volume 2(1), pages 1-9.

Khader K. (2010). The effectiveness of an educational program on Jordanian nurses' attitudes toward caring for dying patients. Unpublished doctoral disertation. The University of Jordan, Amman, Jordan.

Mak, Y.W., Chiang, V.C.A., \& Chui, W.T., (2013). Experiences and perceptions of nurses caring for dying patients and families in the acute medical admission setting. International Journal of Palliative Nursing, vol. 19

Matsui M., \& Braun K. (2010). Nurses' and care workers' attitudes toward death and caring for dying older adults in Japan. Int $J$ Palliat Nurs, volume 16, pages 593-8

Nozari M, Dousti Y., (2013). Attitude toward death in healthy people and patients with diabetes and cancer. Iran $J$ Cancer Prev; volume 6, pages 95-100.

Payne S, Dean S, Kalus C A., (1998) Comparative study of death anxiety in hospice and emergency nurses. J Adv Nurs; 28: $700-6$

Randhawa, (2012). "Death and organ donation: meeting the needs of multiethnic and multifaith populations," British Journal of Anaesthesia, vol. 108, no. Suppl 1, pp. i88-i91

Wessel, E.M., \& Garon, M. (2005). Introducing reflective narratives into palliative care home care education. Home Healthc Nurse, volume 23 , pages 516-22.

Wong, T.P., Reker, G.T., \& Gesser, G. (1994). Death attitude profilerevised: A multi dimensional measure of attitudes toward death. In R.A. Neimeyer (Ed.), Death anxiety handbook: Research, instrumentation

Zyga, S., Malliarou, M., Lavdaniti M., Athanasopoulou M, Sarafis P., (2011). Greek renal nurses' attitudes towards death. J Ren Care, volume 37(2), pages 1017. 